\title{
Paleoenvironmental interpretation through the analysis of ostracodes and carbonate microfacies: study of the Jandaíra Formation, Upper Cretaceous, Potiguar Basin
} Interpretação paleoambiental por meio de análise das associações dos ostracodes e das microfácies carbonáticas: estudo da Formação Jandaíra, Cretáceo Superior, Bacia Potiguar

\author{
Marcos Antonio Batista dos Santos Filho ${ }^{1 *}$, Enelise Katia Piovesan ${ }^{1}$, \\ Gerson Fauth ${ }^{1}$, Narendra Kumar Srivastava ${ }^{2}$
}

\begin{abstract}
Paleoecological analyses are important tools for the reconstruction of paleoenvironments. This paper had the objective of using analysis of ostracode assemblages and carbonate microfacies of a well (Carbomil) and an outcrop (Quixeré) from the Jandaíra Formation, Potiguar Basin, in order to verify how they corroborate and complement the other. Two paleoenvironments for Carbomil Well (assemblages 1 and 2, respectively marine and brackish to neritic environments) and one for Quixeré Outcrop (assemblage 3, marine environment) were identified through the ostracode assemblage analysis. Thin section analysis allowed the identification of two different facies for Carbomil Well, i.e. bioclastic packstones to wackstones, a marine brackish or restricted marine system; and bioclastic grainstones to packstones, a normal, shallow marine system. High levels of alteration on the samples prevented an adequate analysis of Quixeré Outcrop; however, it seems to point towards a low-energy environment. Overall, information provided by the thin sections corroborate and complement data of the ostracode assemblages, which allowed a higher degree of certainty for the paleoenvironmental analysis.
\end{abstract}

KEYWORDS: Ostracodes; Microfacies of Carbonate; Paleoecology.
RESUMO: Análises paleoecológicas sāo ferramentas importantes para a reconstrução de paleoambientes. Este trabalho teve como objetivo utilizar análises de associação de ostracodes e microfácies carbonáticas de um poço (Carbomil) e um afloramento (Ponto Quixeré) da Formação Jandaira, Bacia Potiguar, a fim de verificar como estes métodos corroboram e complementam um ao outro. Dois paleoambientes para o Poço Carbomil (associaçôes 1 e 2, respectivamente, ambiente marinho e mixo-halino) $e$ um para o Ponto Quixeré (associaçāo 3, ambiente marinho) foram identificados por meio da análise das associaçóes de ostracodes. O estudo das seçöes petrográficas permitiu a identificação de duas fácies diferentes para o Poço Carbomil, packstones a wackstones bioclásticas, representando um sistema marinho salobro ou marinho restrito; grainstones a packstones bioclásticas, indicando um sistema marinho raso normal). As amostras do Ponto Quixeré parecem apontar para um ambiente de pouca energia. Em geral, as informaçöes provenientes da análise das microfácies carbonáticas corroboram e complementam os dados fornecidos pelas assembleias de ostracodes, o que permitiu um maior grau de precisäo na análise paleoambiental.

PALAVRAS-CHAVE: Ostracodes; Microfácies Carbonáticas; Paleoecologia.

\footnotetext{
${ }^{1}$ ITT Fossil, Instituto Tecnológico de Micropaleontologia, Universidade do Vale do Rio dos Sinos - UNISINOS, São Leopoldo (RS), Brazil. E-mails:marcosabsantosfilho@hotmail.com; katiapiovesan@gmail.com; gersonf@unisinos.br

2Universidade Federal do Rio Grande do Norte - UFRN, Natal (RN), Brazil. E-mail: narendra@geologia.ufrn.br

*Corresponding author.

Manuscrito ID: 30159. Recebido em: 30/08/2014. Aprovado em: 26/01/2015.
} 


\section{INTRODUCTION}

Ostracodes are diminutive crustaceans, generally between 0.4 and $1.0 \mathrm{~mm}$ long, characterized by their calcareous bivalve carapace. Due to their extensive fossil record, they are widely used as paleoenvironmental indicators, applying methods such as actualistic comparisons, adaptive morphology of the carapace, and populational structures. Many factors must be considered when proposing a paleoenvironmental model based on ostracodes, like the possibility of the carapaces being allochthonous, the ecological preferences of the studied taxa, and the assemblage composition (Moore 1961, Morkhoven 1962, Horne et al. 2002).

Microfacies, as defined by Brown (1943), refer to the petrographic and paleontological criteria analyzed in thin sections, although nowadays the term has been also used to relate to sedimentological data gathered from hand samples and outcrops as well. Most of the criteria used for paleoenvironmental interpretations in carbonate microfacies are qualitative. Usually, they are based on composition, degradation, and preservation of carbonate grains, textural differences and homogenization, bioturbation, and bio-retexturing of the sediment (Flugel 2004).

The results of this paper are based on the use of the two described tools to propose a paleoenvironmental interpretation for an outcrop and a well in the Jandaíra Formation, of the Potiguar Basin, with the objective of verifying the response of both methods in paleoecological analysis.

\section{STUDIED AREA}

The Potiguar Basin is located in Northeastern Brazil, between the latitudes of 4'10' and 5०50' $S$ and longitudes of $35^{\circ} 00^{\prime}$ and $38^{\circ} 20^{\prime}$, encompassing parts of the States of Rio Grande do Norte and Ceará (Fig. 1). It has an area of approximately $48.000 \mathrm{~km}^{2}$, of which $21.500 \mathrm{~km}^{2}$ are onshore and $26.500 \mathrm{~km}^{2}$ are offshore. It is limited to the South, East and West by the crystalline basement. In its emerged section, "Alto de Fortaleza" limits its Western border, while "Alto de Touros" limits its Eastern one. Its submerged section extends from "Atol das Rocas" to "Fernando de Noronha" archipelago, and is delimitated by a bathymetric depth of 2,000 m (Pessoa Neto et al. 2007).

Sediments of the Potiguar Basin were deposited from the Early Cretaceous onwards, extending to the present. According to Pessoa Neto et al. (2007), the stratigraphic record of basin encompasses three main supersequences: Rift Supersequence, deposited during the Early Cretaceous; Post-rift Supersequence from the Alagoas Age; and Drift Supersequence, from the Albian to the present time.

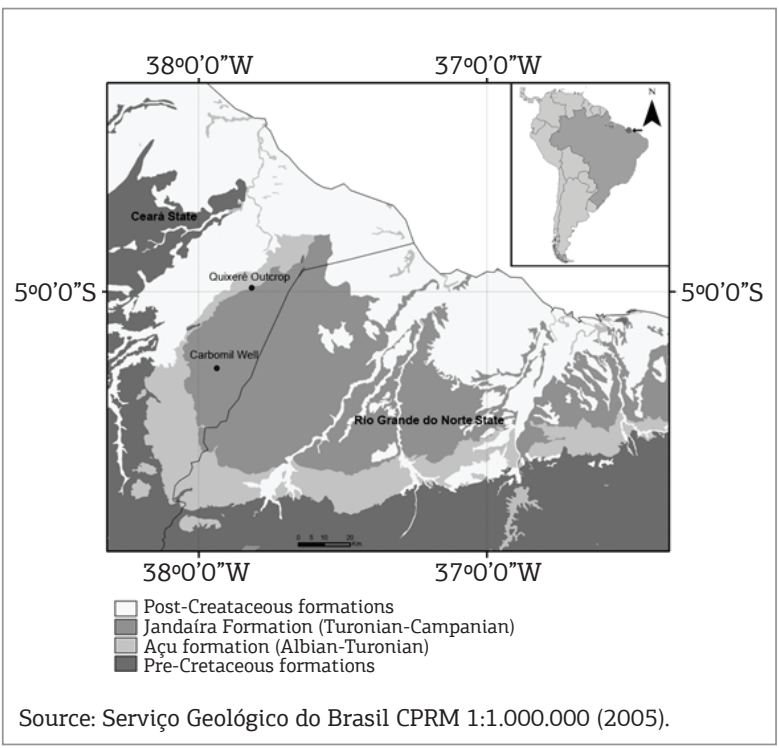

Figure 1. Geologic map of the immersed section of the Potiguar Basin, with the location of the studied areas.

The Jandaíra Formation, which is the focus of this study, belongs to the Drift Supersequence. It is constituted by calcarenites with bioclasts of mollusks, green algae, bryozoans and echinoids, bioclastic lime mudstones and calcilutites with birds eyes structures. Its basal portion is intercalated with sandstones and shales, and its deposits are from tidal flats, lagoons, and platform and open sea environments. The formation represents the great expansion of the carbonate domain, which encompassed the whole emerged area of the basin (Castro et al. 1988). Its upper contact is limited by a regional erosive unconformity that crops out in several places on the onshore section of the basin (Mello 1987). Such place is the richest one in fossils in the Potiguar Basin, including microfossils (foraminifers, microalgae, nannofossils, dinoflagellate, bryozoans, ostracodes, and pollen) and macrofossils (bivalves, gastropods, echinoids, conchostracans, and vertebrates). Sampaio \& Schaller (1968) date this formation as Turonian, Coniacian and Santonian, Tibana and Terra (1981) consider that its age extends from the Turonian to the Maastrichtian; Souza (1982) indicates a Turonian-Campanian range; and finally, Wanderley (1987), based on calcareous nannofossil data, suggests a Turonian-Campanian age, which was reinforced by Viviers et al. (2000) by means of ostracode biostratigraphic studies.

\section{MATERIAL AND METHODS}

Twenty samples from the Jandaíra Formation were analyzed for this paper. Seven of them were from an outcrop 
called Quixeré, located near the town of Quixeré, in Ceará, at the UTM coordinates 23 M 0631254/9448694 (Datum SAD 69), and other 13 from the $11,75 \mathrm{~m}$ well FSBG-11 (denominated Carbomil), which was drilled by Carbomil S/A at the UTM coordinates 23 M 061779/9417902.

The samples were prepared at the Instituto Tecnológico de Micropaleontologia (ITT FOSSIL) of Universidade do Vale do Rio dos Sinos (UNISINOS). They were processed using standard laboratorial techniques to study fossil ostracodes. This consists of disaggregation with hydrogen peroxide $\left(\mathrm{H}_{2} \mathrm{O}_{2}\right)$, washing through sieves with mesh 250, 180 and 63 micrometers, and then they were dried at $60^{\circ} \mathrm{C}$. 1,047 specimens was chosen for this study (amount of specimens per sample can be found on Tab. 1), which was the total amount of ostracodes found from the collected samples. The selected specimens were imaged using a Zeiss EVO MA15 scanning electron microscope.

Thirteen petrographic thin sections were created. Three belong to Quixeré Outcrop, and 10 to Carbomil Well. They were made on the thin section laboratory of UNISINOS. The samples were impregnated with blue resin in order to facilitate the identification of porosity in the rock.

The organization of the data and calculation of the carapace/valve and Simpson index values were performed in the Microsoft Excel and Stratabugs.

\section{RESULTS AND DISCUSSION}

\section{Ostracode assemblages}

The taxonomic identification of the ostracodes was based on Delicio (1994), Delicio et al. (2000), Viviers et al. (2000), Moore (1961), and Morkhoven (1963). Paleoenvironmental interpretations were done following Morkhoven (1963),

Table 1. Total amount of specimens found in the Well Carbomil and Quíxere Outcrop

\begin{tabular}{c|c|c|c}
\hline $\begin{array}{c}\text { Well } \\
\text { Carbomil }\end{array}$ & $\begin{array}{c}\text { Number of } \\
\text { Specimens }\end{array}$ & $\begin{array}{c}\text { Quixeré } \\
\text { Outcrop }\end{array}$ & $\begin{array}{c}\text { Number of } \\
\text { Specimens }\end{array}$ \\
\hline C1 & 16 & Q.1 & 461 \\
\hline C2 & 16 & Q.2 & Barren \\
\hline C3 & 7 & Q.3 & 10 \\
\hline C4 & 7 & Q.4 & 49 \\
\hline C5 & Barren & Q.5 & 1 \\
\hline C6 & 2 & Q.6 & 77 \\
\hline C7 & 9 & Q.7 & 2 \\
\hline C8 & 10 & & \\
\hline C9 & 60 & & \\
\hline C10 & 166 & & \\
\hline C11 & 140 & & \\
\hline C12 & 138 & & \\
\hline C13 & 42 & & \\
\hline
\end{tabular}

Whatley (1988), Cabral (1995), Horne et al. (2002), and Horne (2003) concepts. The ages attributed to the well and outcrop were found according to the ostracode biostratigraphy framework for the Potiguar Basin proposed by Viviers et al. (2000) and Piovesan et al. (2014). The SantonianTuronian age was established to the Carbomil Well due to the presence of Leguminocytheris reymenti Neufville, 1973, whose last occurrence, as provided by Viviers et al. (2000), was in the Santonian. On the other hand, the Turonian age was attributed to the outcrop because of the appearance of Potiguarella sp. 1, whose range is limited to the Turonian as mentioned by Piovesan et al. (2014).

\section{Carbomil well}

Eighteen ostracode species were found in Carbomil Well, separated in 12 genera and seven families (Figure 2A and $2 \mathrm{~B}$ ). Figure $3 \mathrm{~A}$ shows the distribution of the species in each sample of this well.

The faunal analysis has two distinct assemblages:

Assemblage 1 (samples C1 to C7): Brackish water to neritic, composed by the typical brackish genera Perissocytheridea Stephenson, 1938 (characteristic of meso-polyhaline environments, according to Morkhoven (1963), Keyser (1977), Colin et al. (1996)). Also, Fossocytheridea Swain and Brown (1964) (characteristic of marginal marine environments, as per Swain and Brown (1964) and Bergue et al. (2011)), and the marine genera Cophinia Apostolescu, 1961, Ovocytheridea Grakoff, 1951, Bairdoppilata Coryell Sample and Jennings (1935) (a predominately marine genus provided by Kornicker (1961), Morkhoven (1963)) and Triebelina Bold, 1946. It is worth noting that the number of specimens recovered in this assemblage is very low, varying from 2 to 16 , indicating either an environment with poor preservation potential, or one with unfavorable living conditions even for the more tolerant genera (Fig. 2A).

- Assemblage 2 (samples C8 to C13): An exclusive marine assemblage, composed by the genera Cytherella Jones, 1849 (a predominantly marine genus according to Morkhoven (1963), Horne (2003)), Cophinia, Brachycythere Alexander, 1933, Protobuntonia Grékoff, 1954, Soudanella Apostolescu, 1961, Leguminocythereis Howe \& Law, 1936, Bairdoppilata and Paracypris Sars, 1866 (Fig. 2B).

The carapace/valve percentage (Fig. 3B) remains constant through the well. There is a predominance of carapaces on both analyzed assemblages. Usually, this points towards low-energy conditions with fast sedimentation rates (e.g., Pokorný 1964, Oertli 1971, Cabral 1995, Hussain et al. 2007, Hussain \& Kalaiyarasi 2013), which seems to 


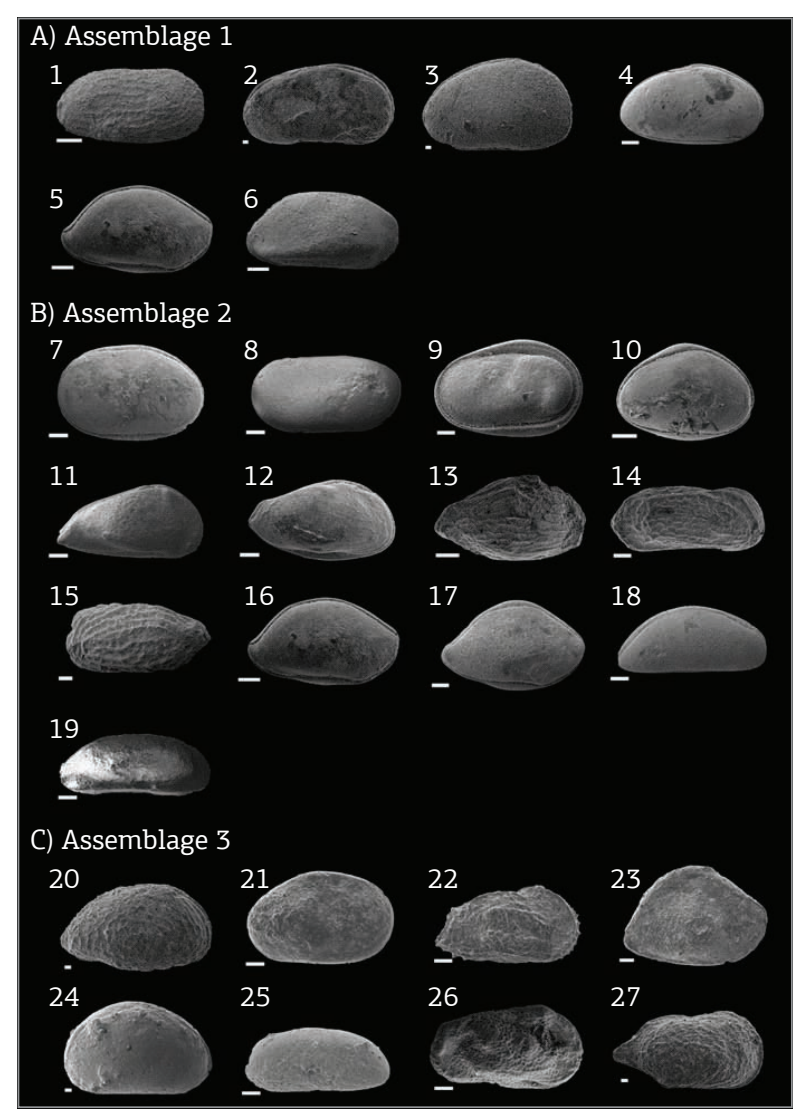

Figure 2. The three defined assemblages. (A) Assemblage 1. Scale bars for Figs. 2 and $3=20$ $\mu \mathrm{m}$, all others are $100 \mu \mathrm{m}$. All figures are right views. 1 - Perissocytheridea sp. 1, Sample C2; 2 Fossocytheridea sp. 1, Sample C3; 3 - Cophinia sp. 1, Sample C4; 4 - Ovocytheridea sp.1, Sample C4; 5 Bairdoppilata sp. 1, Sample C2; 6 - Triebelina sp. 1, Sample C3. (B) Assemblage 1. Scale bars $=100 \mu \mathrm{m}$. Figs. 7, 8, 9 and 15 are left views, all the others are right ones. 7 - Cytherella aff. austinensis Alexander, 1929, Sample C11; 8 - Cytherella mediatlasica Andreu, 1996, Sample C10; 9 - Cytherella gambiensis Apostolescu, 1963, Sample C10; 10 - Cophinia sp. 2, Sample C12; 11 - Brachycythere sp. 1, Sample C9; 12 - Protobuntonia sp. 1, Sample C12; 13 Soudanella semicostelatta Grékoff, 1951, Sample C13; 14 - Leguminocytheris? sp. 1, Sample C10; 15 - Leguminocytheris reymenti, Sample C10; 16 Bairdoppilata sp. 1, Sample C2; 17 - Bairdoppilata sp. 2, Sample C11; 18 - Paracypris posteriusacuminatus Andreu, 1996, Sample C13; 19 - Paracypris sp. 1., Sample C10. (C) Assemblage 3. Scale bars for Figs. 20, 24 and $27=20 \mu \mathrm{m}$, all others are $100 \mu \mathrm{m}$. All figures are right views. 20 - Perissocytheridea sp. 2, Sample Q.1; 21 - Cytherella aff. austinensis, Sample Q.1; 22 Potiguarella sp.1, Sample Q.1; 23 - Bairdoppilata sp. 3, Sample Q.6; 24 - Xestoleberis sp. 1, Sample Q.6; 25 Bythocypris? sp.1, Sample Q.6; 26 - Trachyleberididae gen. et. sp. indet. 1, Sample Q.4; 27 - Cytheruridae gen. et. sp. indet. 1, Sample Q.1. be the case of samples $\mathrm{C} 1$ to $\mathrm{C} 8$. However, samples $\mathrm{C} 9$ to $\mathrm{C} 13$ also present a large amount of fragmented carapaces (Fig. 3D). This situation would be unusual in low-energy environments, possibly indicating a change towards open marine conditions. Therefore, the large amount of carapaces in Assemblage 2 might be attributed to: predominance of species with a more robust hinge; or post-depositional reworking of the sediments. Considering the high variability of energy levels within a marginal setting, it is possible that the fossils deposited on low-energy conditions were posteriorly reworked.

Simpson's index (Fig. 3C) reinforces the idea of an environmental change occurring between samples $\mathrm{C} 8$ and $\mathrm{C} 9$; whereas from $\mathrm{C} 1$ to $\mathrm{C} 8$, the index shows a very low diversity, while from C9 to C13, the diversity increases. According to Pokorný (1971), Cabral (1994) and Puckett (2012), low diversity values are associated with regressive systems tracts, while higher amounts relate to a transgressive one. In the studied samples, the change in ostracode assemblages and carapace/valve percentages seems to corroborate this interpretation. Samples C9 to C13 represent a marine environment, with likely intermediate to high energy levels and a relatively diversified and abundant fauna, which was then, during a regressive event, replaced by the low-energy mixohaline environment (possibly a lagoon) of samples C1 to C8, with a more tolerant but scarce fauna (Tab. 2).

\section{Quiexeré outcrop}

Eight ostracode species were found in Quiexeré Outcrop, separated in six genera and five families. Figure $4 \mathrm{~A}$ shows the distribution of the species in each sample of this outcrop.

The faunal analysis presents a single marine assemblage (Fig. 2C), composed of the brackish genera Perissocytheridea and the marine genera Cytherella, Potiguarella Piovesan, Cabral and Colin (2014), Bairdoppilata, Xestoleberis and Bythocypris? Brady, 1880, with one unidentified Trachyleberididae genera (Trachyleberididae gen. et. sp. indet. 1), and another Cytheruridae genera (Cytheruridae gen. et. sp. indet. 1).

A cyclic fall and rise of abundance of ostracodes can be seen in Figure 4A; whereas Sample Q.1 has over 400 specimens, Sample Q.2 is barren. The number of specimens slowly increases through samples Q.3 and Q.4, and decreases once more on Q.5. More increase followed by another fall in abundance happens from Sample Q.6 to Q.7. The carapace to valve percentage (Fig. 4C) remains constant in the studied samples, which may represent low-energy level settings, with fast sedimentation rates. Differently from Carbomil Well, few carapaces are fragmented. There is, however, a high abundance of Perissocytheridea valves compared to the amount of valves from other genera. As this genera is characteristic of brackish 
Marcos Antonio Batista dos Santos Filho et al.

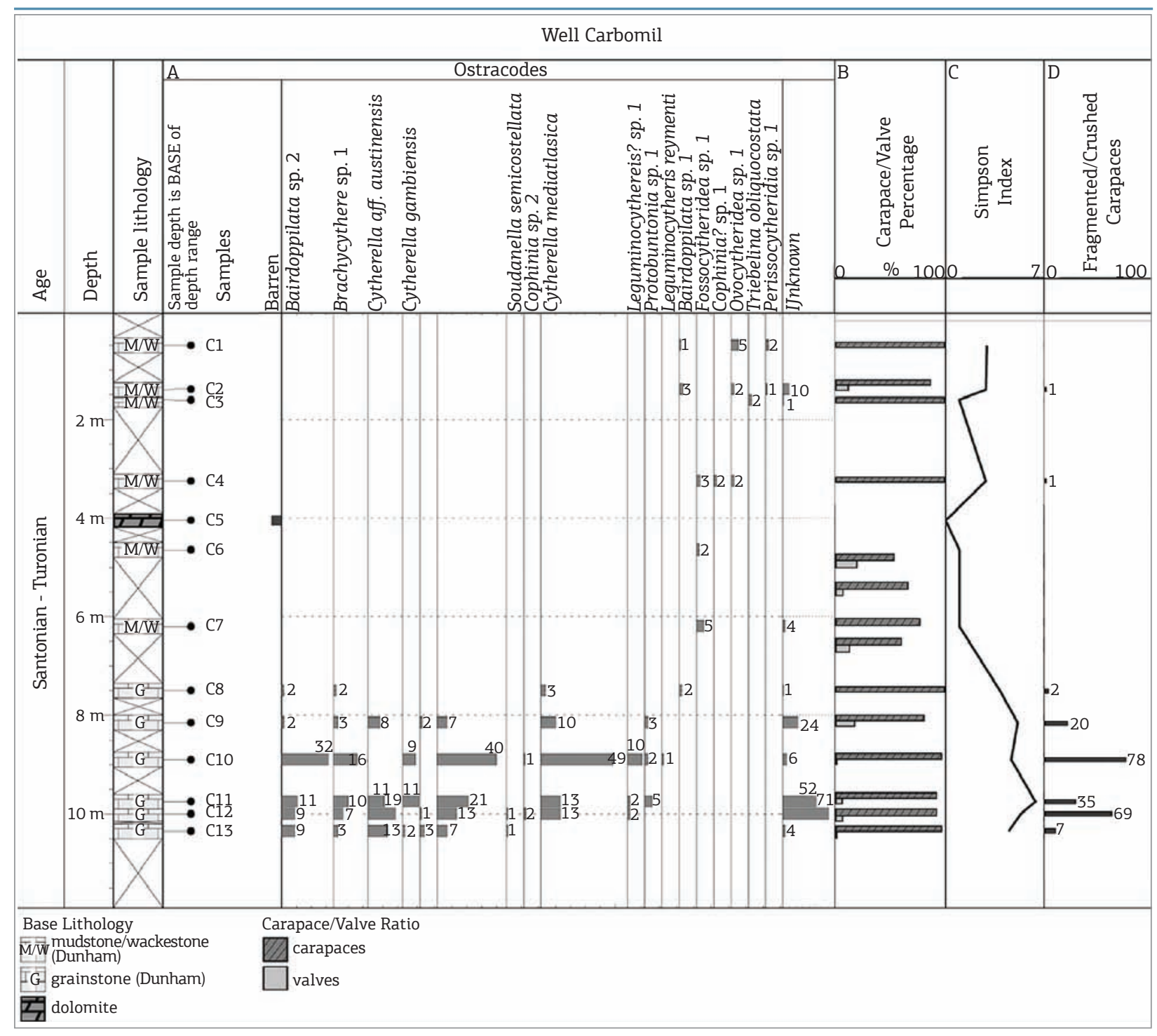

Figure 3. Species distribution (A), carapace/valve percentage values (B), Simpson's index values (C) and amount of fragmented/crushed carapaces (D). Missing values in the carapace/valve ratio indicate either a barren sample or one with less than five individuals. "Unknown" refers to ostracodes whose genera or species could not be identified due to poor preservation of the specimens.

Table 2. Total amount of specimens and number of species for the two assemblages of Well Carbomil

\begin{tabular}{l|c|c}
\hline Samples & $\begin{array}{c}\text { Total amount of } \\
\text { specimens }\end{array}$ & $\begin{array}{c}\text { Number of } \\
\text { Species }\end{array}$ \\
\hline C1 - C8 & 67 & 6 \\
\hline C9 - C13 & 546 & 13 \\
\hline
\end{tabular}

environments, and as all other genera present are inhabitants of normal marine environments, it seems probable that these Perissocytheridea valves are allochthonous.

Simpson's index (Fig. 4B) shows a high diversity on samples Q.1 to Q.4, with lower values on Q.5 to Q.7. The mentioned interpretation of Simpson's index values proposed by Pokorný (1971), Cabral (1994) and Puckett (2012) can provide an explanation for the cyclic rise and fall of ostracode communities, with gradual transition from a transgressive system tract (samples Q.1 to Q.4) to a regressive one (Q.5 to Q.7).
The latter is less diversified, probably due to unfavorable ecological conditions.

\section{Thin sections}

Paleoenvironmental interpretations based on carbonate microfacies followed primarily the works of Flugel (2004) and Córdoba (2001), with Scholle \& Ulmer-Scholle (2003) used as complementary bibliography.

\section{Carbomil well}

Thin section analysis allows the delimitation of two distinct environmental conditions:

- Sections C2, C4, C5, C6, and C7 are primarily bioclastic wackstones/bioclastic mudstones (with the exception of $\mathrm{C} 5$, a porous dolomite, as seen in Figure 5C). C2 (Figs. 5A and 5B) has a high bioclast variety, with 


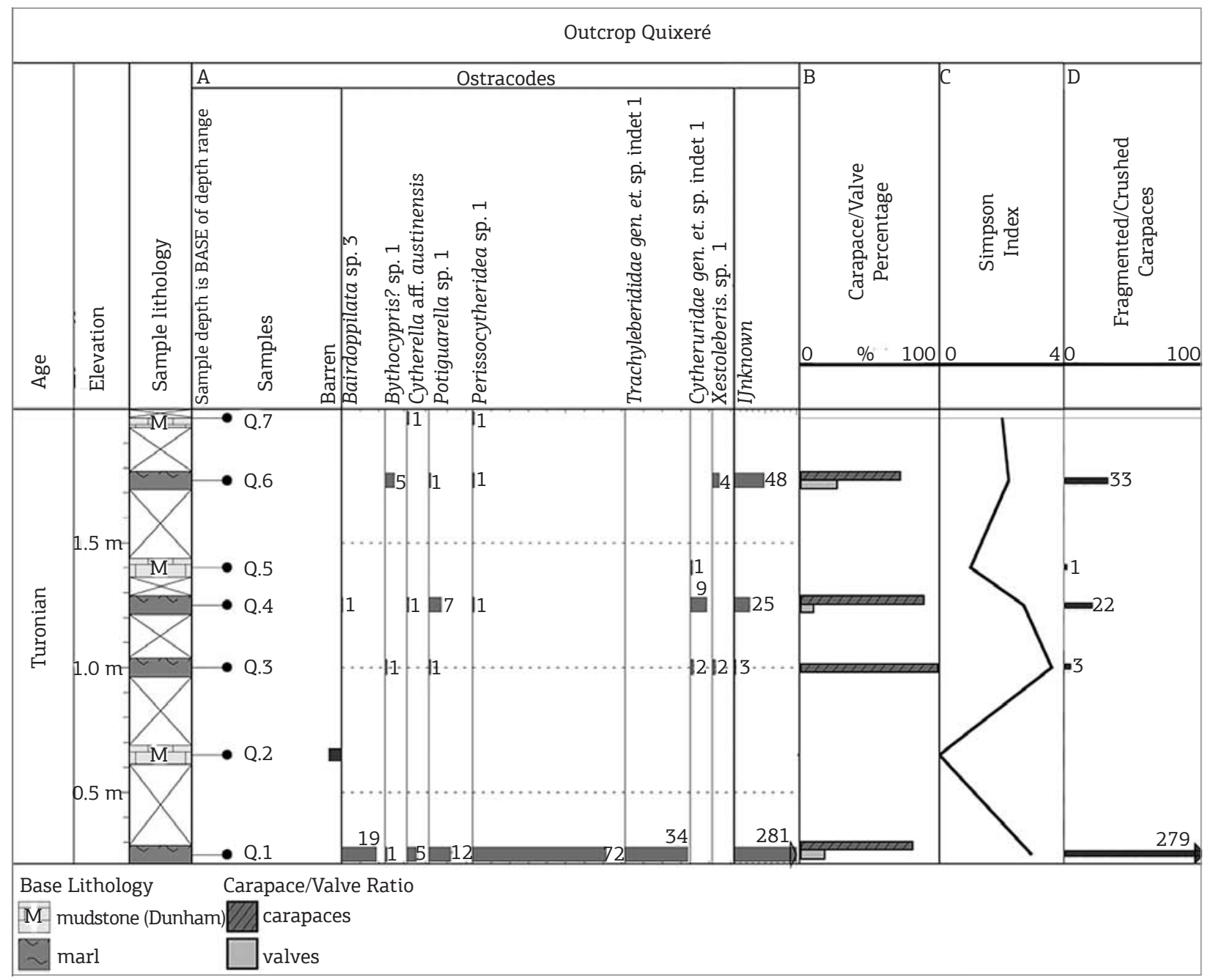

Figure 4. Species distribution (A), carapace/valve percentage values (B), Simpson's index values (C) and amount of fragmented/crushed carapaces (D). Missing values in the carapace/valve ratio indicate either a barren sample or those with less than five individuals. "Unknown" refers to ostracodes whose genera or species could not be identified due to poor preservation of the specimens.

gastropods, miliolids, benthic foraminifera, and bivalves. Diversity decreases greatly in the subsequent sections (Figs. 5D to 5F). Dolomite appears frequently on all samples, both replacing calcite and, much less frequently, as dissolved rhombohedric crystals. There is a large amount of micrite in the samples, both as matrix and as altered bioclasts. Based on these elements, the rocks were classified as belonging to the bioclastic packstones to wackstones facies described by Córdoba (2001). These facies were deposited on low-energy levels due to their association with higher energy facies, and it can be inferred that they represent regions of lower energy on a system dominated by high-energy conditions. These facts point towards a marine brackish or restricted marine system, and lower energy environments that allowed the precipitation of the carbonate mud, with salinity ranges that permit a less diverse biota to be developed.
Sections C9, C10, C11, C12 and C13 are bioclastic grainstones (Fig. 6). All of them have a high diversity of bioclast, with ostracodes, echinoderms, green algae, bryozoans, miliolids, and bivalves. Dolomite occurs much less frequently, being entirely absent on sections C10 to C12. Micrite is present as bioclast alteration. Ostracode carapaces are predominantly articulated; bivalve carapaces, on the other hand, are mostly disarticulated. It is worth noting that longer grains, like echinoderm spikes, seem to be slightly aligned in the same direction, an indicative of the presence of water flow. Based on these elements, these rocks were classified as belonging to the bioclastic grainstones to packstones facies described by Córdoba (2001), whose low percentage of matrix and sedimentary structures point towards intermediate energy depositional environments. These seem to indicate a normal, shallow 

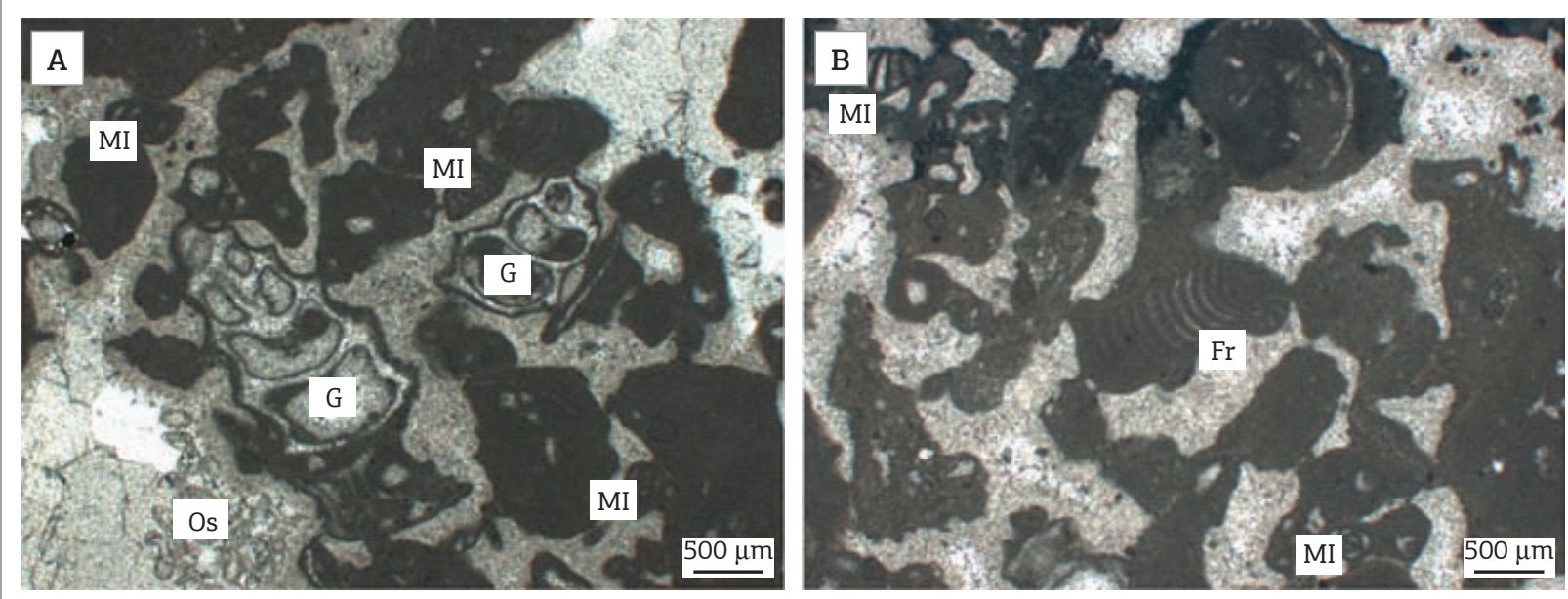

Sample C2

Sample C2
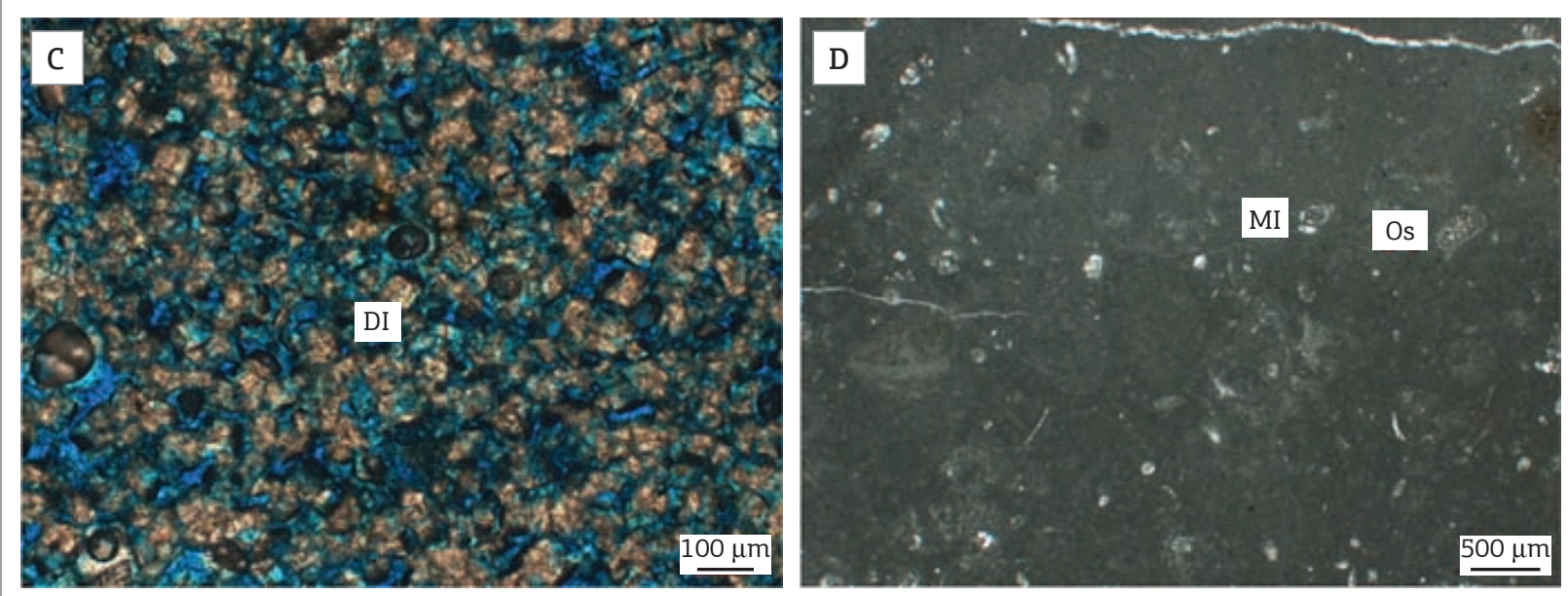

Sample C5

Sample C6
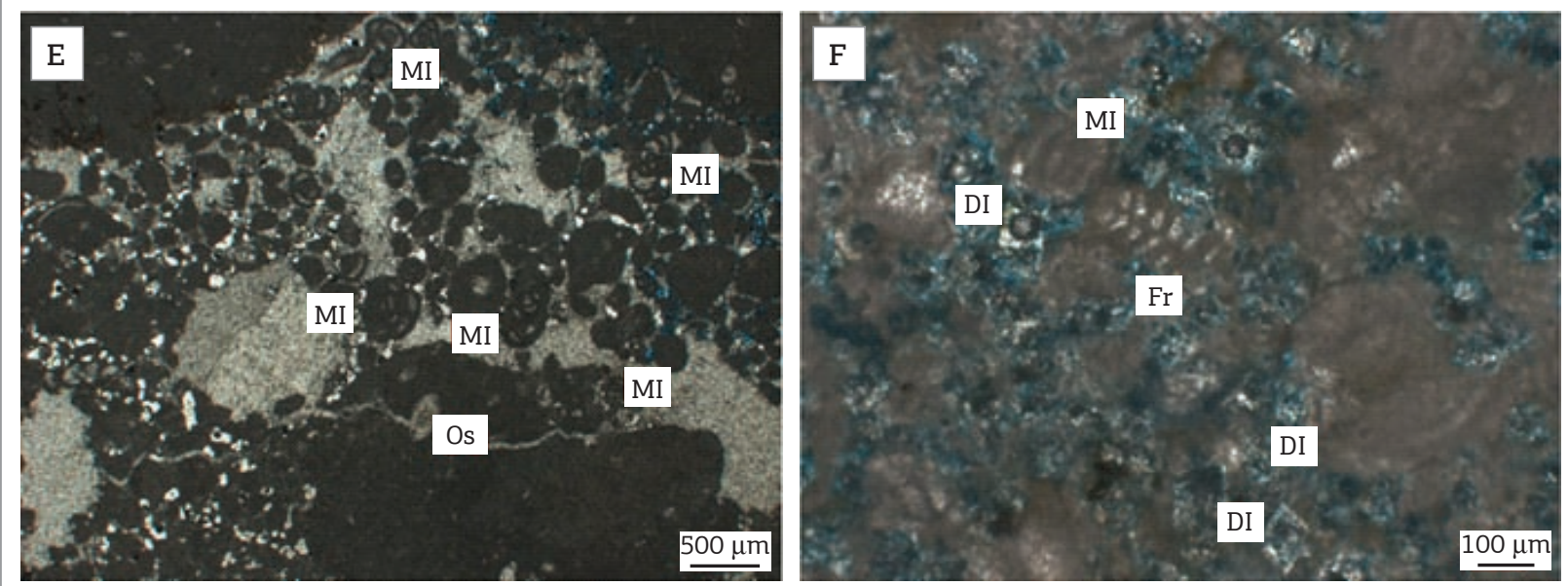

Sample C6

Sample C7

G: gastropods; Ml: miliolids; Os: ostracodes; Fr: benthic foraminifer; Dl: dolomite crystal.

Figure 5. Facies bioclastic packstones to wackstones.

marine system. Echinoderms preferably live in this kind of environment, with a very limited range of salinity tolerance. Green algae are most common at depths of 2 to $30 \mathrm{~m}$, and the aligned longer grains and disarticulated bivalves indicate a higher level of energy (although seemingly not enough to disarticulate the ostracode carapaces), which is a characteristic of open and larger bodies of water. 

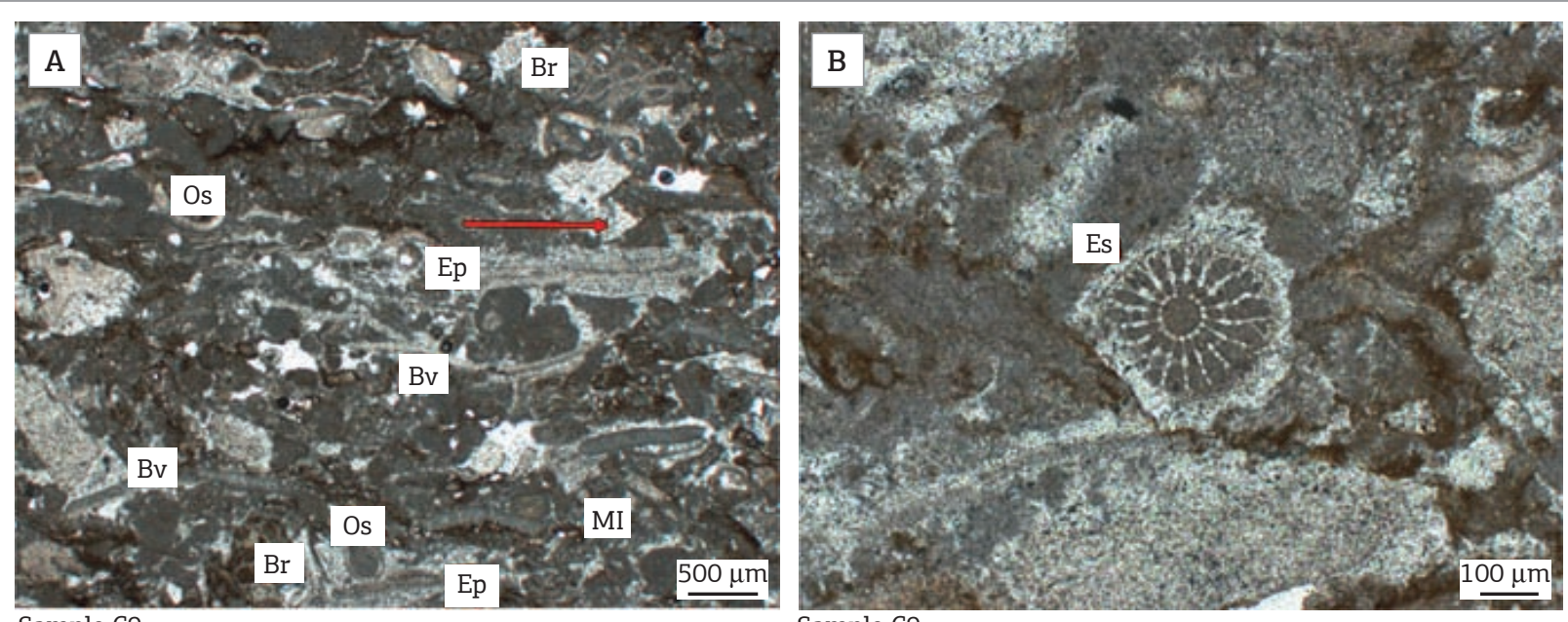

Sample C9

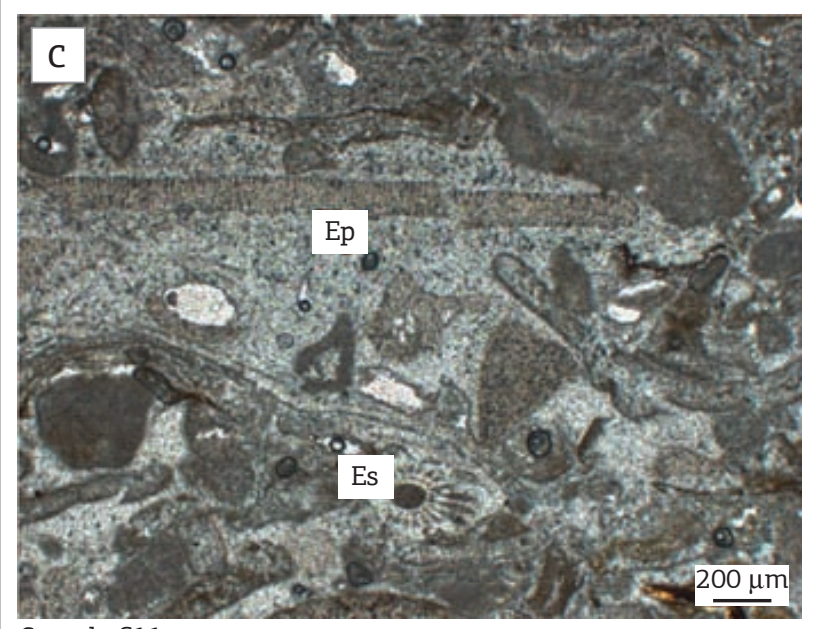

Sample C11

Sample C9

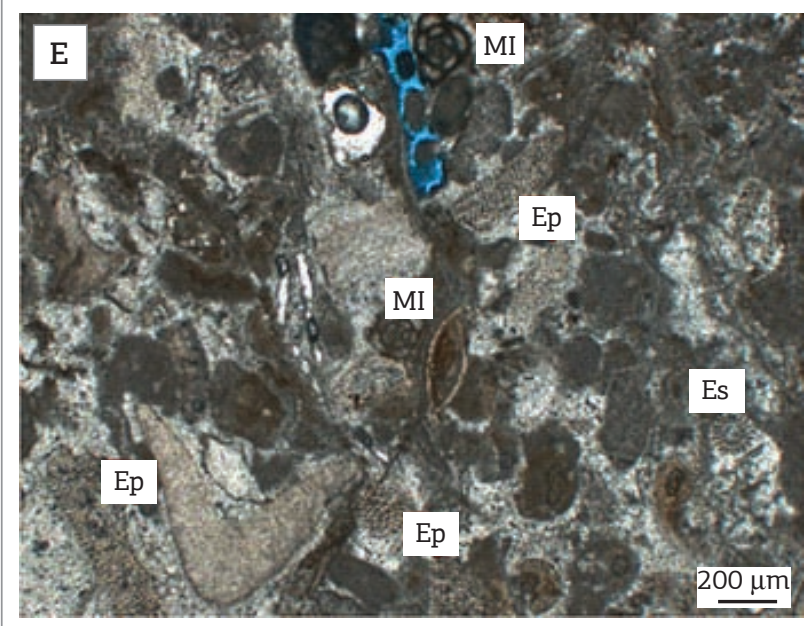

Sample C13

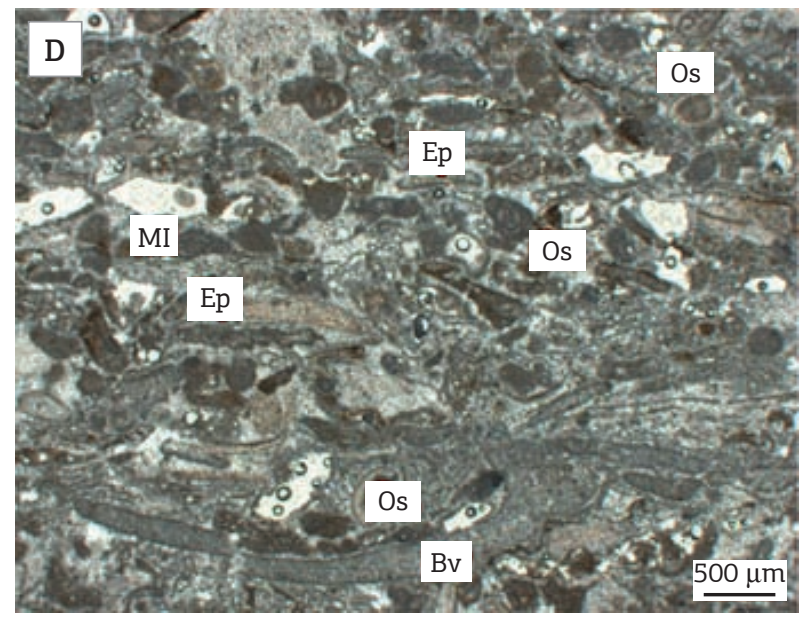

Sample C11

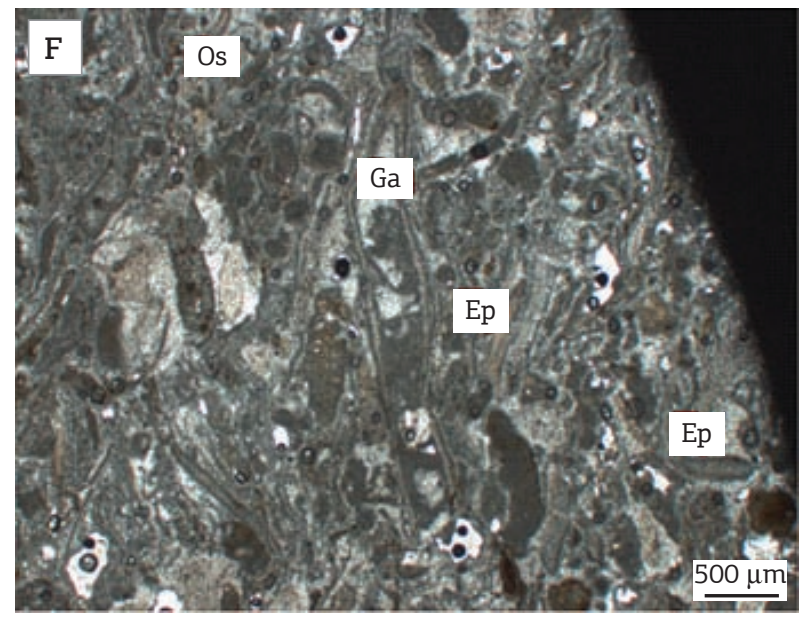

Sample C13

The arrow on image A merely calls attention for the presence of water flow; it does not indicate its direction. Br: bryozoans; Ep: echinoid plate; Es: echinoid spike; Bv: bivalves; Ga: green algae.

Figure 6. Facies bioclastic grainstones to packstones.

\section{Quiexeré outcrop}

The three sections (Q.2, Q.5 and Q.7) are very similar, classified as peloidal mudstones (Fig. 7). They have very few bioclasts of bivalves and ostracodes (Fig. 7A and B). Iron oxide replacing pyrite is present in all samples, being especially common at section Q.5 (Fig. 7B). Except for 


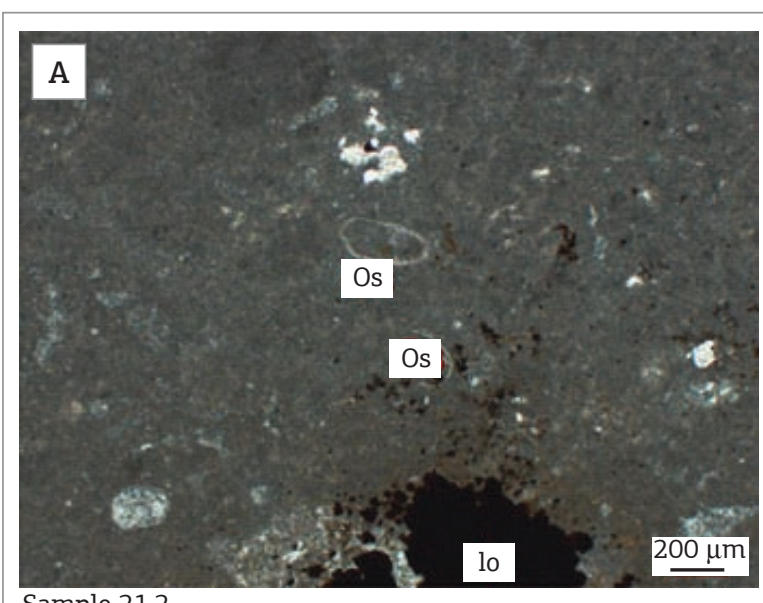

Sample 21.2

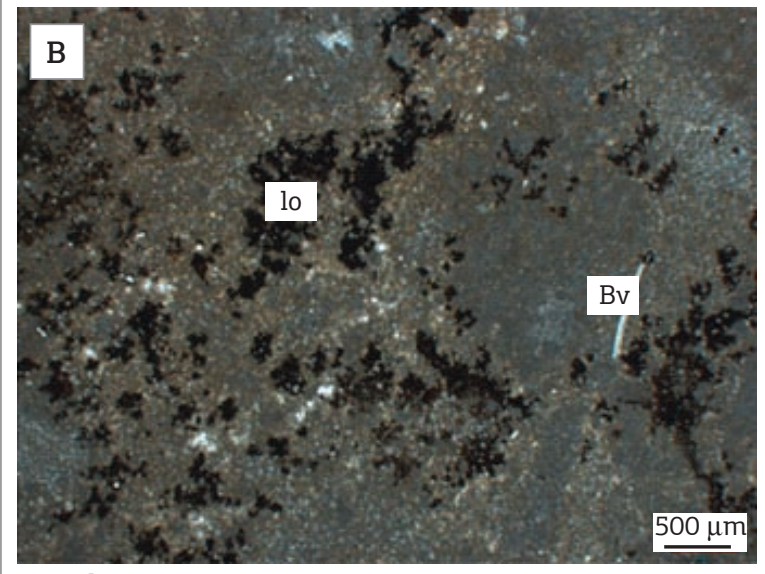

Sample 21.5

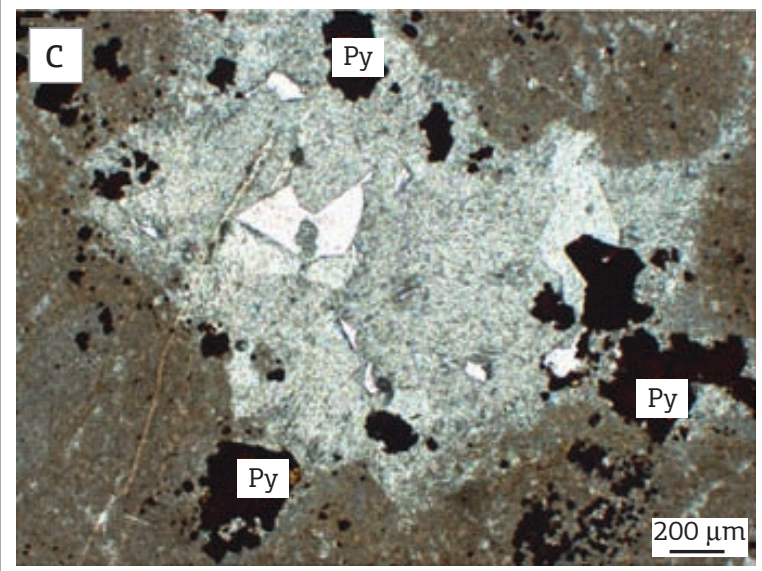

Sample 21.7

Io: iron oxide; Py: oxidized pyrite.

Figure 7. Thin sections Q.2 to Q.7.

these elements, the sections are essentially composed by micrite, with a few zones including calcite or dolomite crystals. Presence of pyrite crystals (Fig. 7C) might be an indication of a reductive ambient, providing a possible explanation for the general lack of bioclasts in the analyzed sections. The large amount of micrite is common in low-energy environments, like a lagoon or a restricted marine environment. However, it is important to mention that there is a high degree of alteration derived from pedogenesis in this outcrop, which severely limits the useful data that can be gathered from these thin sections. Thus, it was not possible to include these thin section analyses in any of the facies described by Córdoba (2001) to these rocks.

\section{Data integration}

Previous paleoenvironmental reconstructions using ostracode assemblages for the Jandaíra Formation tend to represent marginal settings, which are coherent with the interpretation proposed in this paper, for instance, Delício et al. (2000) suggest a shallow marine environment, with characteristic outer neritic biofacies for the formation.

Thin section analysis also attribute marginal/marine settings for the Jandaíra Formation, also in agreement with the proposed depositional ambient in this investigation. Monteiro \& Faria (1988), using both macroscopic descriptions and thin sections from the bottom and top of the 9-MO-13-RN well (coordinates $05^{\circ} 10^{\prime} 03,001^{\prime \prime} \mathrm{S}, 37^{\circ} 21^{\prime}, 160$ ” $\mathrm{N}$ ), attributed to the formation a tidal flat environment. Córdoba (2001) identified 20 distinct depositional facies, separated in three distinct groups: the first one, carbonate facies, demonstrates facies associations that range from the shallow/intermediate waters to deep-sea ones, with the predominance of the first two.

Figures 8 and 9 show a summary of the data compiled from the analysis of both ostracode assemblages and carbonate microfacies.

Information provided by the thin sections agree in general with the data obtained through the analyses of the ostracode assemblages.

The low-energy, marine brackish or restricted marine facies ascribed to thin sections C2, C4, C5, C6 and $\mathrm{C} 7$ correspond to the ostracodes of Assemblage 1, composed of brackish and marine genera and whose carapace/valve percentage also point towards a low-energy environment.

The intermediate to high-energy marine facies attributed to sections C9, C10, C11, C12 and C13 matches the fauna of Assemblage 2, composed entirely of marine genera. Analysis of the thin sections shows the presence of water flow and that the rock suffered compression during diagenesis, which is a possible explanation for the high number of broken carapaces. The high carapace/valve ratio of the ostracode assemblage is at 


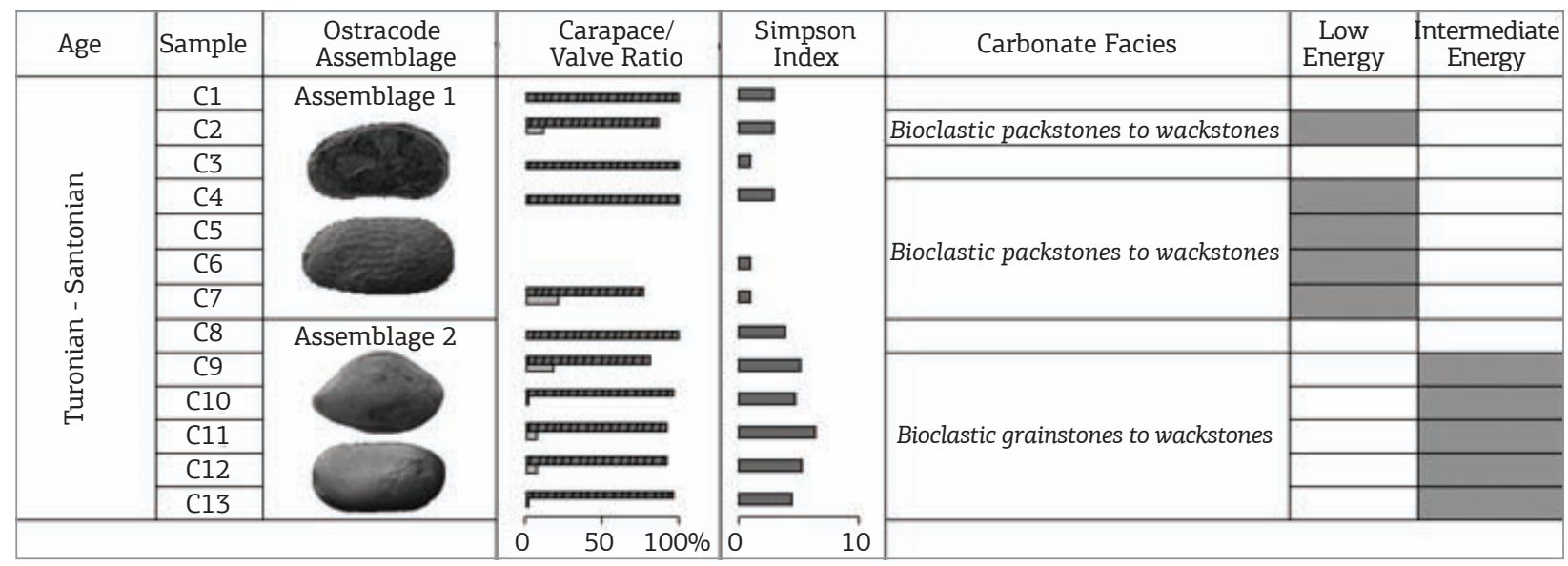

Figure 8. Data integration of Carbomil Well. Figured ostracodes are Fossocytheridea sp. 1, Perissocytheridea sp. 1, Bairdoppilata sp. 2 and Cytherella mediatlasica. Crosshatched bar in the Carapace/Valve ratio column indicates number of carapaces, while the light grey bar shows the amount of valves.

\begin{tabular}{|c|c|c|c|c|c|c|c|}
\hline Age & Sample & $\begin{array}{c}\text { Ostracode } \\
\text { Assemblage }\end{array}$ & $\begin{array}{l}\text { Carapace/ } \\
\text { Valve Ratio }\end{array}$ & $\begin{array}{l}\text { Index } \\
\square \\
\square \\
\square \\
\square \\
\square\end{array}$ & Carbonate Facies & $\begin{array}{c}\text { Low } \\
\text { Energy }\end{array}$ & $\begin{array}{c}\text { Intermediate } \\
\text { Energy }\end{array}$ \\
\hline \multirow{7}{*}{ Turonian } & 21.7 & \multirow{7}{*}{ Assemblage 1} & \multirow{6}{*}{ m } & \multirow{7}{*}{$\begin{array}{l}\square \\
\square \\
\square \\
\square \\
\square\end{array}$} & Non-identiflable & & \\
\hline & 21.6 & & & & & & \\
\hline & 21.5 & & & & Non-identiflable & & \\
\hline & 21.4 & & & & & & \\
\hline & 21.3 & & & & & & \\
\hline & 21.2 & & & & Non-identiflable & & \\
\hline & 21.1 & & 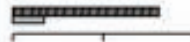 & & & & \\
\hline & & & $50 \quad 100$ & 10 & & & \\
\hline
\end{tabular}

Figure 9. Data integration of Quiexeré Outcrop. Figured ostracodes are Perissocytheridea sp. 2 and Potiguarella sp. 1. Crosshatched bar in the Carapace/Valve ratio column indicates number of carapaces, while the light grey bar shows the amount of valves.

odds with the proposed facies intermediate to high-energy environment; the proposed interpretation for this fact is that carapaces were deposited in lower energy periods inside this high-energy system.

Although specific facies could not be identified to thin sections Q.2, Q.5 and Q.7, their analyses indicate low-energy environments, which are in accordance to the high carapace/valve ratio of Assemblage 3. Furthermore, presence of pyrite in these sections suggest a reductive and low oxygenation depositional environment (Scholle \& Ulmer-Scholle 2003), providing a possible explanation for the decrease of ostracode specimens on those samples.

\section{CONCLUSIONS}

Ostracode assemblage analyses allowed the identification of two distinct paleoenvironments for Carbomil
Well (Assemblages 1 and 2) and one for Quiexeré Outcrop (Assemblage 3). Assemblages 1 and 3 were interpreted as being exclusive marine environments, and Assemblage 2 indicates brackish water to neritic environment. Valve to carapace ratio and Simpson's index analysis for Carbomil Well represent a low-energy mixo-haline environment (samples $\mathrm{C} 1$ to $\mathrm{C} 8$ ) and an intermediate marine one (samples C9 to C13). For Quiexeré Outcrop, the analysis suggests a low-energy marine environment, with a fast sedimentation rate.

Two different facies were identified for Carbomil Well: bioclastic packstones to wackstones (sections C2, C4, C5, C6 and C7), representing a marine brackish or restricted marine system with low energy; and bioclastic grainstones to packstones, indicating a normal, shallow marine system with higher energy levels. Due to the high level of alteration on the samples, the thin section analysis 
for Quiexeré Outcrop was inconclusive, just signaling a low-energy environment.

The sharp decrease in ostracode individuals on Quiexeré Outcrop can be attributed to a change towards a reductive, low oxygenation depositional environment, suggested by the large presence of pyrite in the thin sections for said samples.

Overall, this paper shows that integrating different tools during paleoenvironmental interpretations provides a higher degree of accuracy for theanalysis.

\section{REFERENCES}

Bergue C.T., Fauth G., Vieira C.E.L., Santos A.S. 2011. New Species of Fossocytheridea Swain \& Brown, 1964 (Ostracoda, Crustacea) in the Upper Cretaceous of Santos Basin, Brazil. Revista Brasileira de Paleontologia, 14(2):149-156.

Brown J.S. 1943. Suggested use of the word microfacies. Economic Geology, 38:325.

Cabral M.C.S. 1995. Ostracodeos do Cretácico Inferior do Algarve e da Região de Lisboa: Sistemática, Bioestratigrafia, Aspectos Paleoecológicos e Paleobiogeográficos. PhD Thesis, Universidade de Lisboa, Lisboa, 442 p.

Castro J.C., Viviers M.C., Regali M.S.P. 1988. Stratigraphic Analysis of the Marine Cretaceous in the Eastern Margin of Potiguar Basin. Revista Brasileira de Geociências, 18(2):231-236.

CPRM. 2005. Mapa Geológico do Brasil, escala 1:1.000.000 Serviço Geológico do Brasil.

Colin J.P., Tambareau Y., Krasheninikov V.A. 1996. Ostracodes limniques et lagunaires dans le Crétacé Supérieur du Mali (Afrique de l'Ouest): systématique, paléoécologie et affinités paléobiogéographiques. Revue de Micropaléontologie, 39:211-222.

Córdoba V.C. 2001. A Evolução da Plataforma Carbonática Jandaíra Durante o Neocretáceo na Bacia Potiguar: Análise Paleoambiental. Diagenética e Estratigráfica. PhD Thesis, Universidade Estadual Paulista, São Paulo, 239 p.

Delicio M.P. 1994. Ostracodes Marinhos do Cretáceo MédioSuperior da Bacia Potiguar, RN. Taxonomia, Zoneamento e Correlação Bioestratigráfica. MS Dissertation, Universidade Federal do Rio Grande do Sul, Porto Alegre, 59 p.

Delicio M.P., Coimbra J.C., Carreno A.L. 2000. Cretaceous marine Ostracodea from the Potiguar basin, Northeastern Brazil. Neues Jahrbuch für Geologie und Palaöntologie, Abhandlungen, 215(3):321-345.

Flugel E. 2004. Microfacies of Carbonate Rocks. Analysis, Interpretation and Application. Springer Berlin Heidel. N. Y., 976 p.

Horne D.J., Cohen A., Martens K. 2002. Taxonomy, Morphology and Biology of Quaternary and Living Ostracodea In: Holmes, J.A. \& Chivas A.R. (eds.) The Ostracodea Applications in Quaternary Research. American Geo. Union, Washington, DC, p. 5-36.

Horne D.J. 2003. Key Events in the Ecological Radiation of the Ostracodea, In: Park L.E. \& Smith A.J. (eds.) Bridging the Gap: Trends in the Ostracode Biological and Geological Sciences. The Paleontological Society Papers, 9, p. 181-201.

Hussain S.M., Ganesan P., Ravi G., Mohan S.P., Sridhar S.G.D. 2007. Distribution of Ostracodea in marine and marginal marine habitats off Tamil Nadu and adjoining areas, southern east coast of India and Andaman Islands: Environmental implications. Indian Journal of Marine Sciences, 36(4):369-377.

Hussain S.M. \& Kalaiyarasi A. 2013. Distribution of Ostracodea in the Mullipallam Lagoon, near Muthupet, Tamil Nadu,
Southeast Coast of India - Implications on Microenvironment. In: Sundaresan J., Skreekesh S., Ramanathan A.L., Sonnenschein L., Boojh R. (eds.) Climate Change and Island and Coastal Vulnerability. Capital Pub. Co., Springer, p. 166-176.

Keyser D. 1977. Ecology and Zoogeography of Recent BrackishWater Ostracodea (Crustacea) from South-West Florida, In: Löffler H. \& Danielopol D. (eds.) Aspects of Ecology and Zoogeography of Recent and Fossil Ostracodea. Proceedings of the 6th International Symposium on Ostracodes, Saalfelden (Salzburg), p. 207-221.

Kornicker L.S. 1961. Ecology and taxonomy of recent Bairdiinae (Ostracoda). Micropaleontology, 7:55-70.

Mello U.T. 1987. Evolução Termodinâmica da Bacia Potiguar e Implicações na Manutenção do Petróleo. MS Dissertation, Universidade Federal de Ouro Preto, Ouro Preto, 186 p.

Monteiro M.C. \& Faria R.T. 1988. Planície de Maré no Poço 9-MO13-RN, Formação Jandaíra, Um Exemplo do Passado. Anais do XXXV Congresso Brasileiro de Geologia, Belém, Pará, 2, p. 809-823.

Moore R.C. 1961. Treatise on invertebrate Paleontology, Part Q. Arthropoda 3. Geol. Soc. America, University of Kansas Press, Lawrence, Kansas, 442 p.

Morkhoven F.P.C.M. 1962. Post-Palaeozoic Ostracodea their Morphology, Taxonomy and Economic Use - Volume I - General. Elsevier Publ. Co., 204 p.

Morkhoven F.P.C.M. 1963. Post-Palaeozoic Ostracodea their Morphology, Taxonomy and Economic Use - Volume II - Generic Descriptions. Elsevier Publ. Co., 478 p.

Oertli H.J. 1971. The Aspect of Ostracode Faunas-a Possible New Tool in Petroleum Sedimentology. In: Oertli H.J. (ed.) Paléoécologie des Ostracodes. Paris, Bull. Centre Rech. Pau - SNPA, 5 suppl., p. 137-151.

Piovesan E.K., Cabral M.C., Colin J.P., Fauth G., Bergue C.T. 2014. Ostracodes from the Upper Cretaceous of the Potiguar Basin, Northeastern Brazil: Taxonomy, Paleoecology and Paleobiogrography, Part 1: Turonian. Notebooks on Geology, 14(12):211-252

Pessoa Neto O.C., Soares U.M., Silva J.G.F., Roesner E.H., Florencio C.P., Souza C.A.V. 2007. Bacia Potiguar. Rio de Janeiro. Boletim de Geociências da Petrobras, 15(2):357-369.

Pokorny V. 1964. Some Palaeoecological Problems in Marine Ostracode Fauna, Demonstrated on the Upper Creaceous Ostracodes of Bohemia (Czeckoslovakia). Napoli. Publ. Staz. Zool., 33:462-479.

Pokorny V. 1971. The Diversity of Fossil Ostracode Communities as an Indicator of Paleogeographic Conditions. In: Oertli H.J. (ed.) Paléoécologie des Ostracodes. Paris, Bull. Centre Rech. Pau - SNPA, 5 suppl., p. 45-61.

Puckett M.T. 2012. Paleogeographic Significance of Muscle Scar in Global Populations of Late Cretaceous Ostracodes. Micropaleontology, 58(3):1-14 
Sampaio A.V. \& Schaller H. 1968. Introdução a Estratigrafia Cretácea da Bacia Potiguar. Boletim Interno da Petrobrás, 11(1):19-44

Scholle P.A. \& Ulmer-Scholle D.S. 2003. A Color Guide to the Petrography of Carbonate Rocks: Grains, Textures, Porosity, Diagenesis. Tulsa: AAPG, $474 \mathrm{p}$

Souza S.M. 1982. Atualização da Litoestratigrafia da Bacia Potiguar. In: $31^{\circ}$ Congresso Brasileiro de Geologia, Anais..., Florianópolis, SBG/Imprensa Oficial do Estado, p. 2392-2406.

Swain F.M. \& Brown P.M. 1964. Cretaceous Ostracoda from Wells in the southeastern United States. Bull. North Carolina Dept. Conserv. Devel., 78:1-55.

Tibana P. \& Terra A.B. 1981. Sequência Carbonática do Cretáceo na Bacia Potiguar. Boletim Técnico da Petrobrás, 24(3):174-183.
Viviers M.C., Koutsoukos E.A.M., Silva-Telles A.C., Bengtson P. 2000. Stratigraphy and biogeographic affinities of the late Aptian-Campanian ostracodes of the Potiguar and Sergipe basins in northeastern Brazil. Cretaceous Research, 21:407-455.

Wanderley D. 1987. Estudo de uma Seção Cretácica da Bacia Potiguar com Base em Nanofósseis Calcários. MS Dissertation, Universidade Federal do Rio de Janeiro, Rio de Janeiro, 162 p.

Whatley R.C. 1988. Ostracodea and Palaeogeography, In: De Deckker P., Colin J.P., Peypouquet J.P. (eds.) Ostracodea in the Earth Sciences, Elsevier, p. 103-123.

Arquivo digital disponível on-line no site www.sbgeo.org.br 